\title{
U.S. Policy Toward the Israeli-Palestinian Conflict under the Trump Administration: Continuity or Change?
}

\author{
AYFER ERDOĞAN* and LOURDES HABASH ${ }^{* *}$ \\ * Yıldız Technical University, Turkey \\ ORCID No: 0000-0002-3176-587X \\ ** Birzeit University, Palestine \\ ORCID No: 0000-0003-1658-367X
}

ABSTRACT The 2017 inauguration of Donald Trump as the U.S. president opened a new chapter in U.S. policy making toward the Israeli-Palestinian conflict. Several developments that have taken place under the Trump Administration mark a clear rupture from the Oslo Accords in favor of support for Israeli plans to annex a large fraction of the West Bank and design a new settlement of the conflict according to its interests. While the U.S. policy toward the Palestinian issue is not radically different under Trump, he does break from former presidents in that he overtly indicates a sharp pro-Israel tilt and has been more transparent about the U.S. position in the conflict. In light of the developments that have taken place in the last three years, this article aims to investigate the main pillars of the U.S. policy toward the Israeli-Palestinian conflict and to analyze how far the Trump Administration's policies toward the conflict indicate a shift from those of his predecessors. It also offers some insights into the future of the Israeli-Palestinian conflict by providing three prospective scenarios and discussing their repercussions.

Keywords: U.S. Foreign Policy, Israeli-Palestinian Conflict, Trump Administration, Deal of the Century

Insight Turkey 2020

Vol. 22 / No. 1 / pp. 125-146 


\section{Introduction}

he Israeli-Palestinian conflict, which dates back to the end of the nineteenth century, has been one of the most intractable conflicts in modern history, and it has had far-reaching repercussions in Middle East politics. Since the 1948 Arab-Israeli War, the conflict has revolved mainly around the division of Palestine and the territorial claims of Palestinians over their occupied lands. In the second half of the $20^{\text {th }}$ century, successive wars between Arabs and Israel have resulted in the expansion of the territories of the newly founded State of Israel through occupation.

The Arab-Israeli conflict is driven by various factors and includes religious and historical dimensions. The religious dimension of the conflict is central to both historical and recent events unfolding in the region. Jewish claims grounded on the biblical promise of the "holy land" make up the cornerstones of the conflict. On the other hand, Palestinians' claim to their land is founded on their historical roots. Palestinians refute the claims that the ancient Jewish possession of Palestine dating back to thousands of years ago could prevent Palestinians from continuing their existence and achieving their political rights in their land. Several Arab states have been engaged in the conflict along with the Palestinians because of their religious, ideological and ethnic unity. In addition, the Palestinian cause, particularly after the Second World War, has been at the core of the Arab struggle against Western imperialism and Zionism. The Arab socialist regimes, under Nasser in Egypt and the Baath Party in Syria and Iraq in the second half of the $20^{\text {th }}$ century, viewed Arab unity and the struggle for the Palestinian cause as central to Arab nationalism, which constituted the very political foundation of their regimes, ${ }^{1}$ while Islamist groups in the Arab World advocated the necessity of liberating Jerusalem and the Palestinian land for religious reasons.

It was not until 1991 that the United States officially stepped in to resolve the conflict as a mediator between Israel and the Palestinian Liberation Organization (PLO). Negotiations between the PLO and the Israeli government resulted in the Oslo Accords which seemed like a landmark moment in the search of peace at the time. The Oslo Accords required a five-year transitional period for the withdrawal of Israeli forces from the occupied territories and the establishment of a Palestinian National Authority (PNA). The PLO agreed to formally recognize the State of Israel, and in turn it was granted limited self-governance in Gaza and the West Bank. Nonetheless, the Oslo Accords failed to make inroads into any lasting peace or an independent state for the Palestinians.

By 2000, the short-lived momentum initiated by the Oslo Accords had come to an end. The Palestinians came to an understanding that the so-called peace 
accords did little to put an end to their grievances. The ongoing occupation denied them basic rights such as self-rule, the right to free access to Jerusalem, the refugees' right of return, property rights and security. Deeply resenting the violation of their basic rights, as well as their lack of economic progress as promised by the Oslo Accords, Palestinians declared the Second Intifada which broke out soon after the collapse of negotiations between then Israeli Prime Minister Ehud Barak and then President of Palestine Yasser Arafat.

\section{Ironically, while being deeply sensitive to Jews' historical roots in Jerusalem and Israel's security needs, Trump has paid no regard to the Palestinian national concerns}

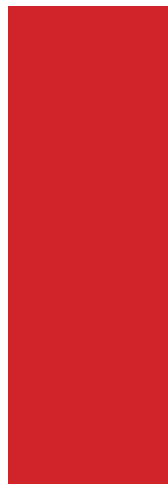

Since the Second Intifada, Israel has increased its military presence, expanded its settlements in the West Bank and tightened its blockade on Gaza. Evidently, the peace process that began more than two decades ago is officially dead; many of its provisions have been abandoned, except that the PNA has been recognized as a legitimate force for governance in the Palestinian territories. Successive Israeli governments have opposed a meaningful two-state solution and the Israeli population is largely indifferent to a lasting peace process. The Palestinians, on the other hand, have become convinced that Israel's main interest is to expand its settlements in the West Bank through force of arms and to tighten its control over security and the economy in the PNA.

Since the beginning of the 1990s, the U.S., which has cast itself in the role of a mediator or peace broker, has been the most influential actor in the trajectory of the Israeli-Palestinian conflict. Particularly after the September 11 attacks, U.S. efforts to mediate the Israeli-Palestinian conflict intensified as part of a wider strategy of maintaining peace and stability in the Middle East. However, having neglected the huge power disparity between Israel and the PNA and the fact that the relationship between the two parties is that of an occupation in which the Israeli state keeps a tight rein on all aspects of life in the PNA rather than a mere conflict, the U.S. has failed to prove itself a credible and effective mediator or a peace broker in the conflict.

Despite his promise to initiate a peace process in the Middle East during his electoral campaign, U.S. President Donald Trump complicated the Israeli-Palestinian conflict further by taking steps that aim to widen the power gap between Israel and the PNA in favor of the former. Ironically, while being deeply sensitive to Jews' historical roots in Jerusalem and Israel's security needs, Trump has paid no regard to the Palestinian national concerns. With its claim to advance "the cause of peace," the Trump Administration's policies have mainly focused on systematically ending the sustainability of the twostate solution. 
The U.S. failed to act as a credible mediator by coordinating its position with Israel and allowing it to set the timetable for negotiations

This article will examine U.S. policy toward the Israeli-Palestinian conflict under Trump and discuss whether it indicates a radical change from those of his predecessors. It is divided into three sub-sections: the first section provides an overview of U.S. policy making toward the Israeli-Palestinian conflict since its onset; the second analyzes the political developments that have taken place under the Trump Administration and assesses Trump's policy making with respect to the conflict; and the third offers prospective scenarios for the future of Palestine under the Trump Administration.

\section{An Overview of U.S. Foreign Policy Toward the Israeli-Palestinian Conflict}

If there is one common policy that all U.S. administrations share, it is the foreign policy vis-a-vis the Israeli-Palestinian conflict. There are two main pillars of the U.S. policy toward the conflict: the denial of Palestinian statehood and the handling of the Palestinian issue simply as a refugee issue; and support for the State of Israel and its Jewish character in political, economic and military terms.

\section{U.S. Denial of Palestinian Statehood}

When we look at the successive U.S. administrations' policy toward the Israeli-Palestinian conflict, we see that have demonstrated remarkable sympathy towards the Israeli state while denying the Palestinian people's rights, particularly the right to self-determination. At the root of the problem lies the fact that successive U.S. administrations have turned a blind eye to the fact that the Israeli-Palestinian conflict was mainly about occupation, the displacement of millions of refugees and the ongoing expansion of Jewish settlements in the West Bank. That the U.S. has dealt with Palestinians as refugees rather than as a nation with the right to statehood is evident in White House official documents such as the foreign policy document by President Richard Nixon in which he describes the Palestinians as refugees. ${ }^{2}$ Even when U.S. administrations dealt with Palestinians as refugees, however, it is clear that their support for the right of return for Palestinian refugees to their homeland was verbal, not actual. Instead, they supported Palestinian settlements in the neighboring Arab countries. ${ }^{3}$

When the PLO was established to be the sole legitimate representative of the Palestinians, the U.S. adopted a hostile policy toward it and considered the PLO as a terrorist organization obstructing peace. The successive U.S. admin- 


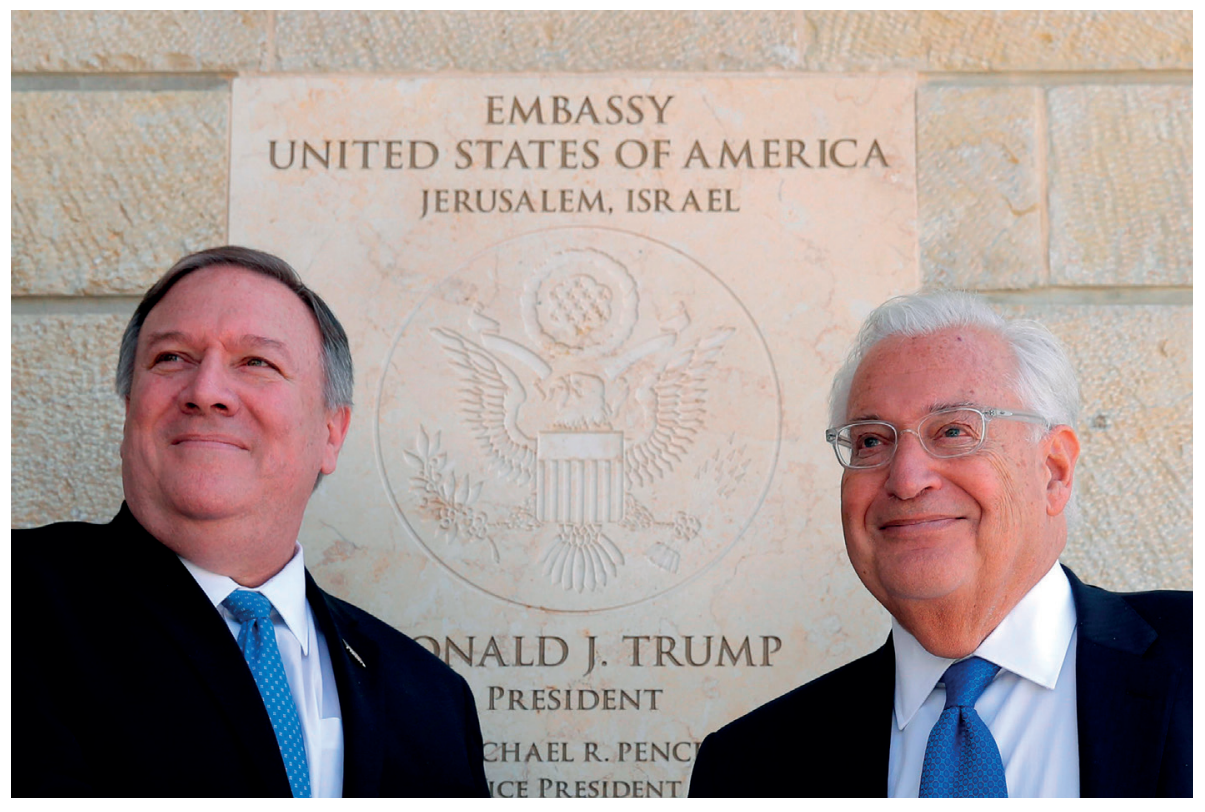

istrations carried on the same hostile policy toward the PLO by ceasing contact and closing its offices in an attempt to wipe out the organization. ${ }^{4}$ Nonetheless, the Palestinian Intifada and the change in the PLO's diplomatic stance forced the Reagan Administration to open a dialogue with the PLO. ${ }^{5}$ The dialogue channel granted by the Reagan Administration didn't bear any tangible outcome as it ended only eight months after George H. W. Bush took office. ${ }^{6}$ The Bush Administration also precluded the PLO from participating in the International Peace Conference in 1991, which forced the Palestinians to participate as part of the Jordanian delegation. ${ }^{7}$ In short, the Palestinians' right to self-determination, their statehood and representation in the international arena was undermined under the Bush Administration. ${ }^{8}$

The Oslo Accords, once seen as a historical breakthrough, raised optimism given that they recognized the Palestinians' aspirations for statehood. The Accords did not fully materialize however due to Israel's nonfulfillment of its obligations. The failure of the Oslo Accords can be attributed to three main reasons: First, the Accords suffered from ambiguity and the absence of a clearly articulated basis in international law. To achieve clarity and fairness, it was essential for the Accords to engage a third party that would monitor the peace process impartially using certain mechanisms for monitoring and accountability. ${ }^{9}$ The U.S. failed to act as a credible mediator by coordinating its position with Israel and allowing it to set the timetable for negotiations. ${ }^{10} \mathrm{Sec}-$ ond, no timeline was set to implement the various stages of the Accords. The outcome was repetitive attempts to keep the parties at the negotiating table,
U.S. Secretary of State Mike Pompeo (L) and U.S. Ambassador to Israel David Friedman (R), in front of the dedication plaque for the U.S. Embassy in Jerusalem, March 21, 2019.

JIM YOUNG / AFP via Getty Images 


\section{The U.S. and Israel enjoy one of the strongest political and military alliances in the world. U.S. political support to Israel has been not only about Palestine but also regional geopolitics}

while the Israeli withdrawal from the West Bank never materialized. ${ }^{11}$ Third, there was a lack of political will on the side of the Israeli government to implement the deal. For instance, the Likud Party severely opposed the deal with the PLO and its leader Benjamin Netanyahu did his best to freeze the Oslo process. Ehud Barak, former prime minister and leader of the Labor Party, was similarly unwilling to cease illegal settlement expansion, one of the most important barriers to peace. ${ }^{12}$ Arguably, the massive imbalance of power between the two parties may have made Israel reluctant to make concessions. Some analysts consider the leadership from both sides responsible for the failure as they did not succeed in gathering a high level of public support for the Oslo process. ${ }^{13}$

Since the launch of the Oslo process in 1993, security cooperation between Israel and the Palestinians has been one of the most controversial and hotly debated issues. Security coordination remains in place despite the fact that the peace process and negotiations were brought to a halt. While Palestinian President Mahmud Abbas defends security coordination as consistent with "Palestinian national interests" and viewed it "sacred," 14 some Palestinians criticize the PNA for its continuation and demand that it be halted for two main reasons. First, they consider security coordination as collaboration with the occupier and a way to legitimize its presence. ${ }^{15}$ Second, Israel has violated each single provision of the Oslo Accords and continues to use brute force against civilians, a clear violation of the Oslo process. ${ }^{16}$ On various occasions, the PNA has threatened to suspend security cooperation, yet did not carry it into effect. ${ }^{17}$ This political stance affects the PNA's legitimacy in the eyes of many Palestinians, who consider the PNA a barrier to resistance. $^{18}$

The Oslo Accords were not the only peace initiative attempted by the U.S. administration. During his office President Bill Clinton struggled to launch the Camp David II Peace Process, which eventually failed. The PNA insisted on Israel's abiding by international resolutions such as its withdrawal from the occupied lands and granting the right of return for refugees. ${ }^{19}$ Although it was Israel that backed down from the deal and dragged its feet over almost all provisions, Clinton put full responsibility on Arafat for the failure of the peace negotiations while complimenting Barak. ${ }^{20}$ In the absence of a real commitment to two-state solution, the U.S.'s rhetorical support for a Palestinian State did not result in any actual step toward peace. 
Similarly, the George W. Bush Administration's policy toward the Palestinian issue was based on refusing any Israeli-Palestinian agreement that would require Israeli concessions, and ruling out any possibility of creating a Palestinian state. As all of the peace proposals presented by the Bush administration were nominal in nature and had no tangible plan to be implemented, they were destined to fail. ${ }^{21}$ In a similar vein, Obama's policies involved not imposing political pressure on Israel, objecting Palestine's membership to the United Nations and supporting Israeli demands for Palestinians' recognition of the Israeli State's Jewish character. ${ }^{22}$

\section{Support for the State of Israel by All Means}

American support for the Zionist movement can be traced back to 1919 when President Woodrow Wilson came to power. ${ }^{23}$ Although Wilson's fourteen principles affirmed the right to self-determination, he sided with the Zionist movement, which denied Palestinians the right to self-determination. This was evident in his approval of the Balfour Declaration before it was officially declared. ${ }^{24}$ Successive American administrations took a firm stand in their policy against the Palestinian issue. President Franklin Roosevelt officially stated in 1944 that the American people and administration sympathize with creating a nation state for the Jews because of the saddening catastrophe which befell thousands of Jews with no home. ${ }^{25}$ His successor Harry Truman continued the biased policy toward the Zionist movement by establishing the Anglo-American Committee which supported creating a Jewish State and urged other countries to approve the partitioning plan. ${ }^{26}$ Under the Truman Administration, the White House recognized the Israeli State only eleven minutes after it was declared. ${ }^{27}$ In addition, the U.S. administrations refrained from referring to Israel's withdrawal from the occupied West Bank. For instance, President Lyndon Johnson stated that Israel would not be forced to evacuate the lands it occupied after the war without peace in exchange. ${ }^{28}$

The U.S. support to the state of Israel manifested itself in three different forms: political support, financial assistance, and military aid. The U.S. and Israel enjoy one of the strongest political and military alliances in the world. U.S. political support to Israel has been not only about Palestine but also regional geopolitics. Two key factors are central to the alliance: first, the U.S. and Israel share common values, interests and goals in the Middle East. ${ }^{29}$ According to mainstream U.S. political thinking, Israel is the only democracy in the Middle East; in a region plagued by failed and failing states and ideologies hostile to the American hegemony, Israel stands as a key ideological ally. In addition, the U.S. and Israel share the same strategic view that depends on a mutual understanding of regional threats and challenges. During the Cold War, Israel was an important partner to the U.S. in the containment of the Soviet threat. Since September 11, 2001, Israel and the U.S. have worked together in the war on 
terrorism. ${ }^{30}$ Today, the perceived Iranian threat brings the two countries closer for regional cooperation.

Second, intelligence sharing has been one of the key components of the alliance between the two states. Israel offers the U.S. vital Middle Eastern human intelligence. The U.S. National Security Agency and Israel's Unit 8200, which is regarded globally as a critical intelligence agency, work closely on various issues including weapons proliferation, terrorism and Iran's nuclear program. ${ }^{31}$

Since Richard Nixon took office in 1969, the U.S. has used its veto to block any resolution that condemned Israel and its policies against the Palestinians in the United Nations Security Council (UNSC). ${ }^{32}$ The Reagan Administration alone used the veto 18 times in the UNSC to protect Israel from international pressure. ${ }^{33}$ The Reagan Administration fully aligned itself with Israeli interests, recognized the legitimacy of Israeli settlements and opposed the preceding Jimmy Carter Administration's resolution that referred to settlements as a violation of international law. ${ }^{34}$ George $\mathrm{H}$. W. Bush also prioritized fending off any threats against Israel and used the veto to block any resolution condemning Israel's policies against Palestinians. ${ }^{35}$ Until 2019, the U.S. used its veto power against Israel-related UN Security Council draft resolutions 44 times to block UNSC resolutions condemning Israeli violations of Palestinian rights. ${ }^{36}$ The only exception $\mathrm{w}$ was under the Obama Administration, when the U.S. abstained on Resolution 2334, which condemned Israeli settlements in the West Bank. ${ }^{37}$

U.S. foreign aid to Israel has been a major component of strengthening the historical ties dating back to the U.S. support for the creation of Israel. ${ }^{38}$ Military assistance makes up nearly all U.S. bilateral aid to Israel although Israel has also received notable economic assistance from the U.S. Since 2011, the U.S. has granted approximately $\$ 3$ billion in grant annually. ${ }^{39}$ U.S. foreign aid to Israel has risen to around $\$ 3.8$ billion since 2017, indicating the U.S. commitment to Israel security and defense. ${ }^{40}$ Despite its economic and military power, Israel has depended on U.S. aid for the provision of certain high-cost U.S. weapon systems. The U.S. military aid has allowed Israel to build its domestic defense industry and today Israel is one of the top global suppliers of arms.

\section{U.S. Policy toward the Israeli-Palestinian Conflict Under the Trump Administration}

During his presidential campaign in 2016, Donald Trump made a number of assertive promises regarding the Middle East and proclaimed that he would strike a grand peace deal to resolve one of the most intractable conflicts in 
history. ${ }^{41}$ It was a matter of concern among analysts both within and outside the U.S. whether Trump's policy toward the protracted political stalemate between the Israelis and Palestinians would indicate continuity or change. More recently, Trump announced the "deal of the century," despite keeping the details of the deal secret. These remarks, however, beg the questions: "Does the U.S. have the political will to make peace real?" and "Can the U.S. Middle East peace plan be a basis for a viable deal between Israel and Palestine?"

The United Nations and the European Union, along with much of the international community adopted a perspective of conflict resolution that could find a middle ground between the Israeli and Palestinian interests. The solution to the conflict, according to this mainstream opinion, lay in the withdrawal of Israel to the pre-1967 borders, or at least close to them, with some slight changes to address Israeli concerns, the establishment of a Palestinian State

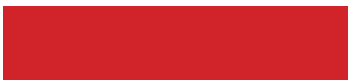

The American approach to peace negotiations was to bring the Palestinian side to the table and encourage them to start negotiating with Israel on the issues that were unclear and ambiguous and thus could easily be manipulated in the future and the recognition of East Jerusalem as the future Palestinian capital. According to the general opinion of the international community, peace should also require Israel to recognize Palestinian refugees' rights of return to their homeland within the pre-1967 borders of Israel. However, although successive U.S. administrations expressed their political will to achieve a peace deal in the Middle East, they remained vague on the details of a peace agreement. Many contested issues, such as the borders between Israel and the PNA, the borders of the area of East Jerusalem proposed to be the future capital of the Palestinian State and the status of refugees were all shrouded in mystery. The American approach to peace negotiations was to bring the Palestinian side to the table and encourage them to start negotiating with Israel on the issues that were unclear and ambiguous and thus could easily be manipulated in the future.

On the other hand, although the previous U.S. administrations did not genuinely take Palestinians' concerns into consideration or endorse the Palestinian position on any of those issues in reality, they at least rhetorically accepted these matters, gave them a symbolic nod, and tried to persuade the PNA come to terms with Israel on a deal. What has changed with the Trump Administration is that the U.S. has reversed past peace efforts that had taken a more balanced approach into one that is completely and overtly pro-Israel. Instead of leading the two parties to reach a consensus under American auspices, the Trump Administration is trying to impose its own model for a peace deal 


\section{Trump's declaration of his recognition of the Golan Heights as being under Israeli sovereignty set a precedent for Israel's several prospective land claims and expansionist policies}

which was in fact created by Netanyahu, the Israeli Prime Minister. Another problem is that Trump assigned his son-in-law, Jared Kushner, with the task of developing the peace plan. Kushner's close ties to Jewish lobbies in the U.S. and the Knesset constitute a further obstacle to achieving peace. Israel has recently drifted so far to the right that any plan proposed by the Knesset would mean the extinction of the Palestinians' aspirations, and therefore would not be acceptable for the PNA. Indeed, a number of moves taken by the Trump Administration in the last three years have proved how far it could complicate the issues on the ground and make peace a long shot.

In late 2017, only a year after he took office, Trump recognized Jerusalem as the capital of Israel and relocated the U.S. embassy to Jerusalem. The decision garnered widespread criticism both in the U.S. and around the world. In his official statement at a diplomatic reception regarding Jerusalem, Trump stated that the previous American presidents' refusal to recognize Jerusalem as the capital of Israel and move the U.S. embassy to Jerusalem in the belief that this would advance the cause of peace did not bring the parties any closer to a lasting peace agreement between Israel and the Palestinians. ${ }^{42}$ While the president introduced his initiative as a "long-overdue step to advance the peace process and to work toward a lasting agreement," ${ }^{33}$ he was vague on how the recognition of Jerusalem as the capital of Israel would advance the cause of peace. The Trump Administration took a similar approach to any discussion of the right of return for Palestinian refugees whose families had been displaced by the occupation of Israel in 1948. In September 2018, Nikki Haley, the then U.S. Ambassador to the UN, stated that the Palestinians' aspirations for the return of refugees and their descendants to their homes within the pre-1967 borders was off the table. ${ }^{44}$

In 2018, the Trump Administration announced that it had cut all U.S. funding to United Nations Relief and Works Agency (UNRWA) whose role had been to provide basic social services to around five million Palestinian refugees in Gaza, the West Bank, Jordan, Syria, and Lebanon. In its official statement, the U.S. administration stated that the agency needed to call on the Palestinians to renew peace talks. The cutting of the UNRWA funding by the U.S. has been perceived as a move to eliminate the Palestinians' right of return, one of the sticking points in the peace talks. Some analysts came to an understanding 


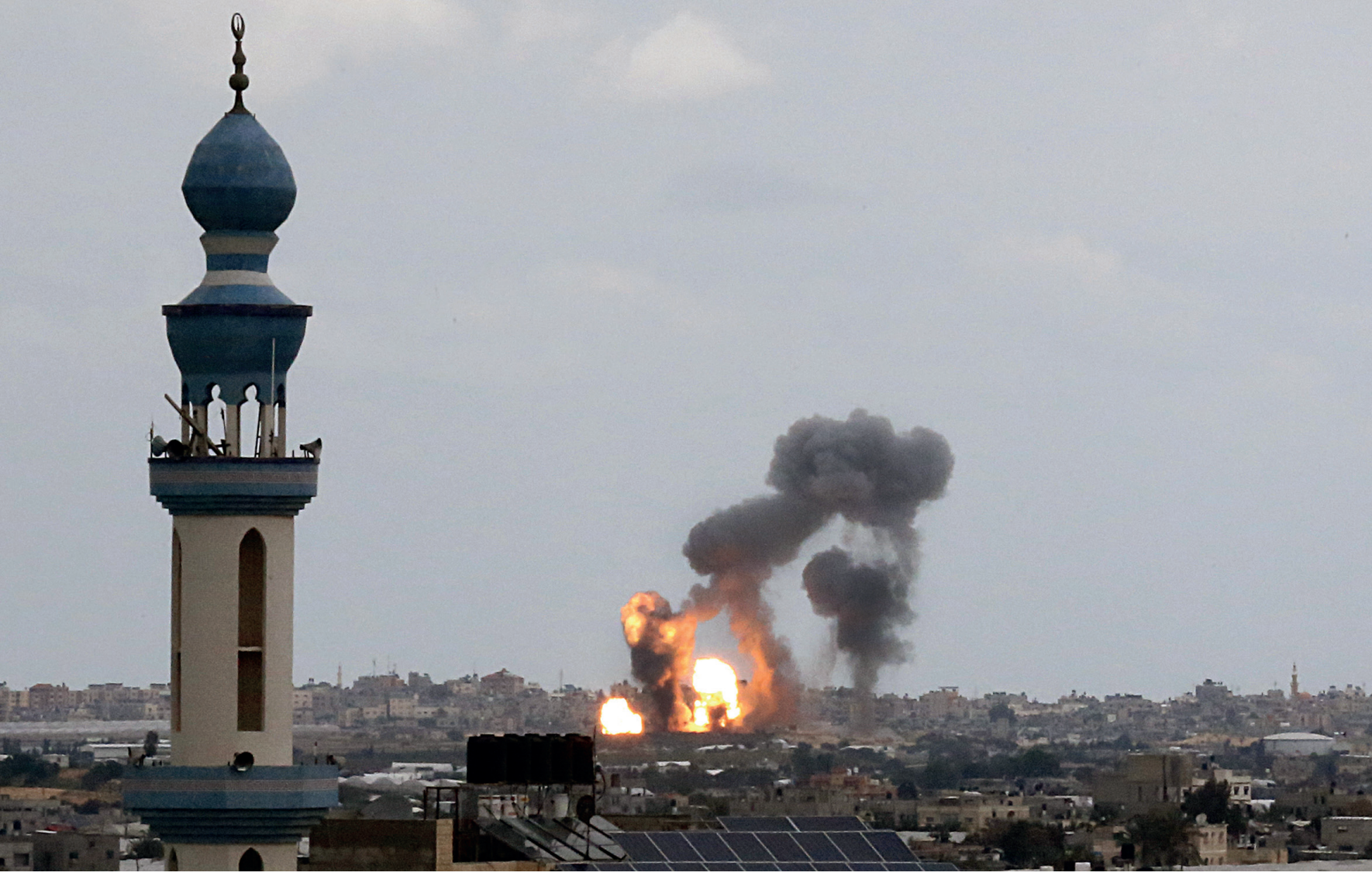

A view of flames and smoke

that the Trump Administration might be attempting to delegitimize the refugee status of Palestinian refugees. ${ }^{45}$ In addition, the U.S. has ceased all USAID assistance to Palestinians in the West Bank and Gaza. These moves were widely perceived as a way of exerting leverage on Palestinian officials to engage in peace talks with Israel and the White House before the Middle East peace plan was officially announced. ${ }^{46}$

In a similar vein, in September 2018 the Trump Administration announced the closing of the PLO office, stating that the PLO has not taken any meaningful steps to advance the start of direct negotiations with Israel and that the PLO leadership had condemned the U.S. peace plan and refused to engage with the U.S. government with regard to peace efforts. The U.S. Department of State officially stated that this decision was "consistent with Administration and Congressional concerns with Palestinian attempts to prompt an investigation of Israel by the International Criminal Court." ${ }^{47}$ Evidently, the U.S. administration was taking a punitive measure against the PLO leadership which had sought to initiate an investigation of Israel by the International Criminal Court. In its statements, the U.S. administration indicated that the PNA would be punished as long as it didn't come to terms with the U.S. position in any prospective peace plan.

A major blow to the peace process has been the expansion of the Israeli settlements in the West Bank. In 1978, the Carter Administration reached a legal opinion that the Israeli settlements in the West Bank were inconsistent with

from explosions caused by an

Israeli air strike in Khan Yunis, southern Gaza Strip, February 24, 2020 .

SAID KHATIB / AFP via Getty Images 
international law and opposed the continued building of civilian settlements in the West Bank since it served as a major obstacle to engage the Palestinians in peace negotiations with Israel. The following president Reagan, on the other hand, did not refer to the settlements as illegal, although he described the Israeli efforts to build new settlements as "unnecessarily provocative." 48

Regardless of these fluctuations, the building of new settlements in the West Bank is indisputably against international law, as the Fourth Geneva Convention Relative to the Protection of Civilian Persons in Time of War states: "The Occupying Power shall not deport or transfer parts of its own civilian population into the territory it occupies." ${ }^{49}$ For decades, the U.S., while not formally repudiating the 1978 State Department legal opinion, abstained from calling the newly built settlements illegal unlike much of the world, including the United Nations, European governments and the Arab states. The Trump Administration reversed four decades of U.S. policy on the Israeli settlements in the West Bank when it declared that the U.S. would no longer abide by the 1978 legal opinion and did not consider the Israeli civilian settlements in West Bank, per se, as inconsistent with international law. ${ }^{50}$ This declaration came on the heels of Israeli Prime Minister Netanyahu's pledge in his electoral campaign to annex the West Bank. ${ }^{51}$ With this declaration, the U.S. not only cleared the way for Israeli settlement expansion but also eliminated an important barrier to the annexation of Palestinian territory.

Trump also officially recognized Israeli sovereignty over the Golan Heights, which had been Syrian territory until Israel occupied it in the Six-Day War in 1967 and annexed it. The annexation was not recognized by the UNSC, which adopted Resolution 497 in 1981, asserting: "The Israeli decision to impose its laws, jurisdiction and administration in the occupied Syrian Golan Height is null and void without international legal effect." 52 Previous U.S. administrations considered the Golan Heights as occupied Syrian territory in line with UNSC resolutions until Trump reversed decades of U.S. policy by defying international law. Trump's declaration of his recognition of the Golan Heights as being under Israeli sovereignty set a precedent for Israel's several prospective land claims and expansionist policies. An emboldened Netanyahu recently pledged to annex the Jordan Valley and the northern Dead Sea as well as the Jewish settlements in the West Bank if he is reelected. ${ }^{53}$

On January 28, 2020, Trump, along with Netanyahu, announced his "peace plan" in a White House press conference to which no Palestinian representative was invited ${ }^{54}$ The plan, which was designed in all its aspects to serve Israeli interests, can be examined on three fronts: political, economic and security.

On the political front, the plan proposes a model of Palestinian statehood that is linked to a long list of conditions that must be fulfilled by Palestinians 
over the course of four years. ${ }^{55}$ Those requirements include the disarmament of Hamas and the Palestinian Islamic Jihad; ${ }^{56}$ the recognition of Israel as a Jewish State; ${ }^{57}$ refrainment from any attempt to become a member of an international organization without the consent of the State of Israel; refrainment from taking any legal action against

\section{While the deal aims to bury the two-state solution, it appears to be tilted toward achieving a Greater Israel and a much-shrunken Palestinian entity}

the State of Israel and the U.S. before the International Criminal Court and other tribunals; the suspension of welfare payments to the families of political prisoners and martyrs killed by the Israeli army; and the provision of welfare services only to those who are not convicted of terrorist acts by Israel. ${ }^{58}$ In addition, the future Palestinian State is expected to establish good governance free of corruption and in full respect to human rights.

Even if the Palestinians were to fulfill each and every condition set by the plan, the Palestinian State referred to in this deal would have only conditional and limited sovereignty, if any. ${ }^{59}$ Jerusalem would remain the undivided capital of the State of Israel. The plan envisions a state of Palestine with a capital on the outskirts of East Jerusalem located in either Kafr Akab or Abu Dis, which could be named Jerusalem by the State of Palestine. ${ }^{60}$ As for refugees, after the agreement, the refugee status of Palestinians would cease to exist and the responsibilities of UNRWA would be transitioned to the relevant governments while only a limited number of the refugees would be allowed to return to Palestine. ${ }^{61}$

The "deal of the century" enables Israel not to withdraw from the lands it occupied in 1967. With the deal, Israel would be able to annex 97 percent of the settlements in the West Bank to its territory ${ }^{62}$ and extend its sovereignty over the Jordan Valley. ${ }^{63}$ Based on the vision of the deal, the size of the Palestinian State would consist of approximately 70 percent of the West Bank and the Gaza Strip. ${ }^{64}$ In other words, while the deal aims to bury the two-state solution, it appears to be tilted toward achieving a Greater Israel and a much-shrunken Palestinian entity.

On the economic front, the deal offers more than $\$ 50$ billion as an investment in the Palestinian economy, society and government over ten years. ${ }^{65}$ The plan also envisions a low tariff scheme with reduced trade barriers and strategic infrastructure investments that would stimulate private sector growth and end the current unemployment crisis. ${ }^{6}$ In addition, according to the deal, the West Bank and Gaza Strip would be linked by an access route that passes through the State of Israel. The Palestinian State could have a port unless it poses a threat to Israel. ${ }^{67}$ 


\section{Saudi Arabia and the other Gulf States are expected to become the main contributors to the economic part of the deal}

On the security front, the deal requires the State of Palestine to be fully demilitarized. The State of Palestine would only have security forces capable of maintaining internal security, preventing terrorist attacks within Palestine and against the State of Israel and ensuring public order and law enforcement. ${ }^{68}$ According to the deal, routes outside of the Palestinian State would be under the control of the State of Israel; Israeli control over the borders would be absolute from the Jordan River to the Mediterranean Sea. ${ }^{69}$

The Trump Administration's one-sided peace plan also grants Israel's permanent apartheid rule a legal status. Unlike the Oslo process where Israel was expected to withdraw from the occupied territories to achieve Palestinian statehood under the formula "land in return for peace," under the "deal of century," Israel gets anything it wants, including the annexation of illegal settlements and the Jordan Valley, without any precondition to be met. Ironically, Palestinians are expected to meet a list of preconditions in order to be entitled to a demilitarized and non-sovereign state which would subsist on less than 15 percent of historic Palestine, which is divided by various fortress-like Israeli settlements. ${ }^{70}$

The Trump Administration seems to be shifting the focus from the Palestinians' political and national concerns to their economic concerns, and proposing economic cooperation and development in the Palestinian territories; in other words, adopting Netanyahu's "economic peace" plan. This approach is based on the false assumption that Palestinians would give up their aspirations for self-determination within a sovereign state in return for some material gains such as investment and free trade. The so-called "peace plan," which eradicates the very existence of the PNA, is destined to fail from its outset as there can be no peace without concessions from both parties. In the long run, the approach taken by Trump and his administration will only serve to expand the existing gap in the power balance between the two parties, marginalize Palestinians, and further destabilize the Middle East. The U.S. administration's partial and one-sided approach toward the Palestinian issue has undermined its credibility and its meditating role in any negotiation.

\section{The Gulf States' Endorsement to the Plan}

That the Gulf States are the key clients of the "deal of the century" became evident in the launching of the so-called "Peace to Prosperity Workshop" hosted in June 2019 by Bahrain, where the Trump Administration announced the economic part of the deal. Later, the representatives of the United Arab Emir- 
ates (UAE), Oman, and Bahrain attended Trump's announcement of the "peace plan" in January 2020. Adel al-Jubeir, Saudi Arabia's Minister for Foreign Affairs, praised the plan stating that it has positive elements for negotiations. ${ }^{71}$ Saudi Arabia and the other Gulf States are expected to become the main contributors to the economic part of the deal. According to some sources, they have already pledged to fund it. ${ }^{72}$

The main driver for the Gulf States' warming relations with Israel appears to be their perceived threat from the Islamic Republic of Iran as "a common enemy." Particularly, Saudi Arabia, the UAE, and Bahrain view Iran as a key security threat. This perception is further exacerbated by the recent attacks on Saudi oil facilities, pipeline infrastructure, and Gulf shipping perpetrated by Iran. By forming a united front with Israel against Iran, these states aim to receive Trump's backing in the Saudi-Iranian rivalry and further their security cooperation with the U.S. More importantly, Saudi Crown Prince Mohammad bin Salman pledged to recognize and normalize trade with Israel on the condition that the U.S. provide support to the prince to defeat Iran and to become the key player in the Middle East. ${ }^{73}$ What is clear from the unfolding of relations between the Gulf, Israel and the U.S. triangle is that the rise of Salman to power in Saudi Arabia and the emergence of Iran as a threat for the Gulf States make it less likely for these strategic Arab states, once vocal critics of Israel, to fight for the Palestinian cause.

\section{Prospective Scenarios for the Future of Palestine}

The current scene with respect to the Israeli-Palestinian conflict leads to scenarios that exclude the possibility of a two-state solution, which has continually been undermined by U.S. administrations. The Palestinian leadership has refused to take part in any peace plan proposed by the Trump Administration after the recognition of Jerusalem as the capital of the state of Israel. It is clear to the Palestinians that any peace plan proposed by the Trump Administration would fall far short of fulfilling their statehood.

With regard to the future of the Palestinian cause lies a central question: "What is the future of the Palestinian cause under the Trump Administration?" Three potential scenarios for the future of the Israeli-Palestinian conflict are proposed below: (i) Coexisting With No Solution, which is divided into the two sub-scenarios "Status Quo" and "Status Quo Plus," (ii) Unilateral Withdrawal, and (iii) State Minus Scenario.

\section{Coexisting with No Solution}

According to the Oslo II Accords (1995), the West Bank was divided into three areas: Area A which comprises 18 percent of the West Bank is under the con- 


\section{Throughout successive administrations, the U.S. policy toward the Israeli-Palestinian conflict has not been characterized by any radical shift. Under the veneer of mediating for peace, U.S. presidents have worked closely with Israel to ensure its political, economic and security interests}

\section{Unilateral Withdrawal}

As Israel's actions on the ground eliminate the possibility of achieving a twostate solution, Israel might implement a unilateral withdrawal policy. Indeed this policy is nothing new as it was implemented in Lebanon in 2000 and in Gaza in 2005. Today, there is an ever-increasing consensus in Israel calling for the expulsion of the Palestinians. ${ }^{75}$ According to this scenario, Israel would draw the borders it desires and maintain the areas behind the apartheid wall. In an interview, Netanyahu mentioned the possibility of withdrawal stating the notion of one-sidedly actions is getting popular in Israel no matter if it is the center left wing or the center right wing of the political spectrum. ${ }^{76}$

The idea behind unilateral withdrawal is to remove the one-state solution from the table. In the absence of a two-state solution, however, Palestinians and Israelis will be forced to live in one state, an outcome that is not welcomed by the majority of Israeli citizens and politicians. Instead of having Palestinians in the state of Israel, the plan would leave some parts of Areas A and B to the Palestinians and confine them to geographically isolated areas under Israel's control. In addition, geographically disconnected entities would allow Israel to disrupt any possibility of creating a Palestinian State while forcing Palestinians to live in much restricted territories and paving the way for the construction of more Jewish settlements.

\section{State Minus}

Most scenarios in the Israeli-Palestinian context would eventually result in the creation of a vague Palestinian entity leading to a "state minus" which refers to a state that has no sovereignty over the land it governs and doesn't have any military force to defend its territory. This would be the outcome of an international debate on how to deal with the Palestinian entity resulting from the scenarios mentioned above. The utmost result would most likely be a cluster of disconnected Palestinian entities. However, Israel would continue to push for creating a state minus despite the fragmentation of these entities. Israel's main concern would be to assure disarmament, as militarization of the Palestinian 


\section{If there is any likelihood of Palestinian statehood, it will be a demilitarized state minus with no sovereignty}

entity is not acceptable. In other words, a state minus with no actual power on the ground would exist.

The state minus scenario coincides with a proposition made by Yoav Kisch, a Knesset member. According to this proposition, Palestinians would administer some sectors such

as health, education, commerce and agricultural services on 40 percent of the West Bank's territory, and Palestinian cities would be connected through means of shared roadways between the Palestinian areas and Israel. As for the remaining territories, they would be annexed to Israel with Jerusalem as its capital. ${ }^{77}$ Netanyahu had previously indicated his approval of creating a demilitarized Palestinian State minus in return for the PNA's recognition of Israel as a Jewish state. ${ }^{78}$ Netanyahu also stated that such a deal would require the Palestinians to give up their demands for the refugees' right to return, and would confirm that the solution of the refugee issue can only be found outside the borders of Israel. ${ }^{79}$ Therefore, the Palestinian State or entity proposed to be established would be devoid of sovereignty, demilitarized and denudated of Jerusalem as its capital.

\section{Conclusion}

Throughout successive administrations, the U.S. policy toward the Israeli-Palestinian conflict has not been characterized by any radical shift. Under the veneer of mediating for peace, U.S. presidents have worked closely with Israel to ensure its political, economic and security interests. The uninterrupted provision of U.S. financial and military aid to Israel is a clear indication of this trend. On the other hand, the U.S. administrations have dealt with the Palestinian issue as a refugee issue rather than as an issue of a nation with historical roots to its lands and existential concerns. The existence of the Palestinians was only recognized rhetorically by the U.S., as is evident in the American refusal to recognize the PLO once it was established. The U.S. administrations have also turned a blind eye to the systematic denial of Palestinians' basic rights by Israel and have struggled to legitimize the Israeli actions as a fight against terrorism.

The last three years under the office of Trump have witnessed several draconian measures faced by Palestinian institutions and the legitimization of Israeli actions which are clearly against international law. The complete alignment of U.S. policies with Israeli interests and demands has ruled out prospects for a meaningful peace settlement and undermined the U.S. role as a credible mediator in the conflict. Trump differs from his predecessors in that his political rhetoric and actions are more overt and ferocious, and his administration 
doesn't claim nonalignment in the Israeli-Palestinian conflict. By declaring the deal of the century, which clearly violates international law and Palestinians' basic rights in all its aspects, the Trump Administration has indeed indicated a shift from the former American administrations, which had at least given the Palestinian cause some symbolic support and attempted to bring both sides to the table. Trump's approach to resolving the conflict is to create a peace plan by engaging in talks with Israel in the background and putting leverage on the PNA to accept the results, despite the evident fact that the PNA cannot comply with the proposed criteria even if it wanted to do so. The recognition of Jerusalem as the capital of Israel, the relocation of the U.S. embassy to Jerusalem, the shutting down of the PLO office in Washington, and the cutting of U.S. funds to UNRWA and USAID were clear indications of the U.S. administration's implementation of the plan before it was officially declared. The deal would only facilitate the annexation of the West Bank, facilitate Israel's expansion of Jewish settlements, and endanger the very existence of the PNA. A very likely scenario is that Israel would annex parts of the West Bank that it regards as fertile in terms of land or critical due to its position in relation to its territory and withdraw from the other parts, which would eventually result in a muchshrunken Palestine. On the other hand, the U.S. administration's backing of a peace deal that only favors Israel at the expense of the Palestinians acts against a viable peace and forms the basis for an unprecedented level of instability and violence in the Middle East.

The Palestinian officials' refusal to engage in peace talks with Israel and the White House can bring other scenarios to the table. Any future scenario promoted by the U.S. and Israel will undermine prospects for the establishment of a Palestinian State with Jerusalem as the capital of the two states. If there is any likelihood of Palestinian statehood, it will be a demilitarized state minus with no sovereignty. All of the prospective scenarios currently on the table are designed to serve the Israeli plan for Greater Israel by various moves, such as the annexation of much of the West Bank, and claims of sovereignty over the Golan Heights and the Jordan Valley.

\section{Endnotes}

1. Ayfer Erdoğan, "From the Free Officers Coup to the Arab-Israeli War of 1967: The Rise and the Demise of the Radicalization Trend in the Middle East," Turkish Journal of History, Vol. 69, No. 1 (2019), p. 177.

2. Hala Abu Baker Saudi, Al-seyasa al-Amricia itijah al-seraa al-Arabi al-Israeli 1976-1973, (Beirut: Center for Arab Unity Studies, 1986), pp. 254-255.

3. Deborah Gerner, "Foras oflitat wa sobol lam toslak, idarat Eisenhower wa al-Falastinion," in Ghassan Salame (ed.), al-seyasa al-Amricia wa al-Arab, (Beirut: Center for Arab Unity Studies, 1985), p. 138.

4. Ibrahim Abu Lughod, "Seyasat America bi-itijah Falastin," in Salame (ed.), al-seyasa al-Amricia wa alArab, p. 330.

5. Ann Lesch, "Ghadarat Raegan seyasatha itijah al-Falastinien," in Salame (ed.), al-seyasa al-Amricia wa al-Arab, p. 268. 
6. Chery Rubenberg, "Idarat Bush wa al-Falastinion: iaadat takieem," in Salame (ed.), al-seyasa al-Amricia wa al-Arab, p. 272.

7. Rubenberg, "Idarat Bush wa al-Falastinion: iaadat takieem," p. 300.

8. Rubenberg, “Idarat Bush wa al-Falastinion: iaadat takieem," pp. 269-270.

9. Roslyn Boatman and Alison Martin, "From Failed to Fair: Learning from the Oslo Accords to Foster a New Rights-Based Approach to Peace for Palestinians and Israelis," Oxfam International, (November 2019), retrieved February 18, 2020, from https://bit.ly/2vJy7FS, pp. 17-18.

10. Jonathan Rynhold, "The Failure of the Oslo Process: Inherently Flawed or Flawed Implementation?" Mideast Security and Policy Studies, No. 76, retrieved February 18, 2020, from https://bit.ly/2SZnl6m, p. 6.

11. Boatman and Alison Martin, "From Failed to Fair," p. 19.

12. Avi Shlaim, "The Rise and Fall of the Oslo Peace Process," retrieved February 18, 2020, from https://bit. ly/39F1HLB, pp. 254-255.

13. Rynhold, "The Failure of the Oslo Process," p. 5.

14. Jessica Purkiss and Ahmad Naf, "Palestinian Security Cooperation with Israel," The Middle East Monitor, (2015), retrieved February 18, 2020, from https://bit.ly/2HAFOMk, p. 9.

15. Julia Lisiecka, "Israeli-Palestinian Security Cooperation: What Next?" European Union Institute for Security Studies (EUISS), (May 2017), retrieved February 18, 2020, from https://bit.ly/2HySmcg, p. 2.

16. Purkiss and Naf, "Palestinian Security Cooperation with Israel," p. 8

17. Purkiss and Naf,"Palestinian Security Cooperation with Israel," p. 9.

18. Purkiss and Naf,"Palestinian Security Cooperation with Israel," p. 8.

19. Mamdouh Nofal, "amaleyat al salam baad Camp David al-thaneya," Journal of Palestine Studies, Vol. 11, No. 43 (Summer 2000), pp. 90-92.

20. Nofal, “Amaleyat al salam baad Camp David al-thaneya,” p. 93.

21. Kathleen Christison, "nehayat hokba sawdaa': Falstin-Israel fi a'hd George Bush al ibn," Journal of Palestine Studies, Vol. 20, No. 78 (Spring 2009), pp. 99-101.

22. Salah Abu Khatleh, "seyasat Obama itijah al-kadeya al-Falastineya 2009-2012," Al-Quds Open University Journal for Research and Study, Vol. 1, No. 36 (June 2015), p. 247.

23. Wahid Abd Al-Hamid, "al alakat al-Falastenya al-Amricia," in Salame (ed.), al-seyasa al-Amricia wa alArab, p. 166.

24. Richard Ned Lebow, "Woodrow Wilson and the Balfour Declaration," Journal of Modern History. Vol. 40, No. 4 (December 1968), p. 501.

25. Adel Ghoneim, "Al-welayat al-motaheda wa al-kadeya al-Falastineya: khilal al-harb al-alameya althaneya 1939-1945," Yearbook of the College of Humanities and Social Sciences, No. 4 (1981), retrieved December 20, 2019, from https://bit.ly/2PM9OyJ, p. 122.

26. Abu Lughod, "Seyasat America bi-itijah Falastin," pp. 328-329.

27. Steven L. Spiegel, The Other Arab-Israel: Conflict: Making American's Middle East Policy from Truman to Reagan, (London: University of Chicago Press, 1985), p. 37.

28. Nicholas Rostow, "al-raees al-Amrici Lyndon Baines Johnson wa harb hozayran/yonyo 1967: al-doros al-mostafada mn al-dawr al-Amrici," Washington Institute, (June 9, 2017), retrieved December 12, 2019, from https://bit.ly/2QeTNQX.

29. Jeremy M. Sharp, "U.S. Foreign Aid to Israel," Congressional Research Service, (August 7, 2019), retrieved February 18, 2020, from https://bit.ly/2MKKOG6, p. 2.

30. Haim Malka, Crossroads: The Future of the U.S.-Israel Strategic Partnership, (Washington, DC: Center for Strategic and International Studies), retrieved February 19, 2020, from https://go.aws/2SBIvbY, p. xvii.

31. Alex Lockle, "Here's Why the U.S. and Israel are Such Close Allies," Business Insider, (February 18, 2017), retrieved February 19, 2020, from https://bit.ly/2v0glyf. 
32. "43 veto Amrici fi khidmat Israel," RT News, (December 18, 2017), retrieved December 18, 2019, from https://bit.ly/2ZjBYEE.

33. William Albert Abrams, "Israel and the Palestinians in U.S. Foreign Policy Past - Present - Future," Unpublished Master's Thesis, University of Georgia, 2006, retrieved December 18, 2019, from https://bit. ly/371RxDI, p. 34.

34. Marty Lederman, "Assessing the New U.S. "View" on the Legality of Israeli Settlements in the West Bank," Just Security, (November 19, 2019), retrieved December 18, 2019, from https://bit.ly/2EZnDnd.

35. Ashraf Abdullah Yassin, "al seyasa al-Amricia wa tatwor amaleyat al-tasweya al-seyaseya bayn al-janebein al-Falastini wa al-Israeli 2001-2008," Alnahda, Vol. 10, No. 4 (2009), p. 58.

36. Sheren Khalel, "Eight Key Moments of U.S. Support for Israel, Long Before Trump's 'Deal of the Century,"' Middle East Eye, (June 22, 2019), retrieved December 18, 2019, from https://bit.ly/37nDCrp.

37. "Al-kadeya al-Falastinia, hakatha tamllasa Trump mn erth Obama," Al Jazeera, (November 20, 2019), retrieved December 18, 2019, from https://bit.ly/2QjwmWR.

38. Israel is the largest cumulative recipient of foreign aid since World War II: "U.S. Foreign Aid to Israel," Congressional Research Service, (June 10, 2015), retrieved December 25, 2019, p. 2, from https://bit. ly/2rlW6n3.

39. "U.S. Foreign Aid to Israel," p. 28.

40. "U.S. Foreign Aid to Israel," p. 2.

41. Richard Sokolsky and Aaron Miller, "Donald Trump's Middle East Promises: Can He Keep Them?" Carnegie Endowment for International Peace, (December 5, 2016), retrieved December 3, 2019, from https://bit.ly/2MKJ1kF.

42. "Statement by President Trump on Jerusalem," The White House, (December 6, 2017), retrieved December 5, 2019, from https://bit.ly/2ZF2AzS.

43. "Statement by President Trump on Jerusalem."

44. Robert Malley and Aaron David Miller, "Trump Is Reinventing the U.S. Approach to the Palestinian-Israeli Conflict," The Atlantic, (September 20, 2018), retrieved December 8, 2019, from https://bit. ly/2F8wyCX.

45. Peter Beaumont and Oliver Holmes, "U.S. Confirms End to Funding for UN Palestinian Refugees," The Guardian, (August 31, 2018), retrieved December 8, 2019, from https://bit.ly/39rjWEU.

46. Yolande Knell, "U.S. Stops All Aid to Palestinians in West Bank and Gaza," BBC, (February 1, 2019), retrieved December 8, 2019, from https://bbc.in/2SEMwNO.

47. Heather Nauert, "Closure of the PLO Office in Washington," U.S. Department of State, (September 10, 2018), retrieved December 10, 2019, from https://bit.ly/2Qebf9o.

48. Bernard Gwertzman, "State Department: About the West Bank and the Emperor's Clothes," The New York Times, (August 25, 1983), retrieved December 15, 2019, from https://nyti.ms/2ss7btj.

49. Gwertzman, "State Department: About the West Bank and the Emperor's Clothes."

50. "Pompeo: U.S. No Longer Considers Israeli Settlements Illegal," Al Jazeera, (November 19, 2019), retrieved December 15, 2019, from https://bit.ly/37u0ohv.

51. Lara Jakes and David M. Halbfinger, "In Shift, U.S. Says Israeli Settlements in West Bank Do Not Violate International Law," The New York Times, (November 18, 2019), retrieved December 10, 2019, from https:// nyti.ms/2ZEYEiF.

52. "Resolution 497: Mideast Situation/Golan-Israel to Rescind Decision Imposing Its Laws, Jurisdiction and Administration in the Occupied Golan Heights," United Nations, (December 17, 1981), retrieved December 13, 2019, from https://bit.ly/37w6l8h.

53. "Netanyahu Announces Post-Election Plan to Annex Jordan Valley," Al Jaazera, (September 11, 2019), retrieved December 18, 2019, from https://bit.ly/2rl6njl.

54. "Peace to Prosperity: A Vision to Improve the Lives of the Palestinian and Israeli People," The White House, (January 2020), retrieved January 29, 2020, from https://bit.ly/2SG4FcZ. 
55. Harkov and Keinon, "The Deal of the Century: What Are Its Key Points?" The Jerusalem Post, (January 29, 2020), retrieved February 18, 2020, from https://bit.ly/2U1Bm5T.

56. "Peace to Prosperity," p. 10.

57. "Peace to Prosperity," pp. 3-4.

58. "Peace to Prosperity," p. 43

59. Brenden McDermid, "Netanyahu Says Israel Is Offering Palestinians 'Conditional' \& 'Limited' Sovereignty, New Capital Will Be at Abu Dis," Reuters, (January 28, 2020), retrieved February 18, 2020, from https://bit.ly/3bSTFAM.

60. "Peace to Prosperity," p. 17.

61. "Peace to Prosperity," p. 33.

62. "Peace to Prosperity," p. 12.

63. "Peace to Prosperity," p. 13.

64. Harkov and Keinon, "The 'Deal of the Century."'

65. "Peace to Prosperity," p. 19.

66. "Peace to Prosperity," p. 19.

67. "Peace to Prosperity," p. 12.

68. "Peace to Prosperity," p. 22.

69. Harkov and Keinon, "The 'Deal of the Century."

70. Jonathan Cook, "The Trump Plan Is Just a Cover for Israel's Final Land Grab," Middle East Eye, (February 4, 2020), retrieved February 18, 2020, from https://bit.ly/2HDDJUZ.

71. "Saudi Foreign Minister Praised Deal of the Century," Middle East Monitor, (February 14, 2020), retrieved February 18, 2020, from https://bit.ly/38PPmEs.

72. "Saudi Arabia and Other Gulf States to Fund U.S. Deal of the Century," Middle East Monitor, (January 28, 2020), retrieved February 18, 2020, from https://bit.ly/38LIHvT.

73. "Bin Salman: Help Us Take Control of Middle East so that We Can Normalize with Israel," Middle East Monitor, (September 30, 2019), retrieved February 18, 2020, from https://bit.ly/2P7zlw0.

74. Sameeh Shbeb, "al-salam al-ektisadi jaded kadim," (February 20, 2017), Al Ayyam, retrieved December 20, 2019, from http://bit.ly/2AGdzfO.

75. Atef Abu Saif, "Israek wa al-masala al-Falastineya.. taseed nahj al-dam wa mohasarat hal al-dawlatin," Madar Strategic Report, (2017), pp. 39-40, retrieved December 20, 2019, from https://bit.ly/2PrtWYH.

76. Yuav Shaham, "14 amaa ala al-ensihab al-Israeli mn Lobnan: awdat aser al-ensihab ohadi al-janeb?" Al Masdar, (May 25, 2014), retrieved December 10, 2019, from http://bit.ly/2AFKxgw.

77. Atef Abu Saif, "Israek wa al-masala al-Falastineya.. taseed nahj al-dam wa mohasarat hal al-dawlatin," p. 54.

78. Toi Staff, "Netanyahu Says Palestinians Can Have a 'State Minus,"' The Times of Israel, (January 22, 2017), retrieved December 25, 2019, from https://bit.ly/36bDtap.

79. "Netanyahu: dawla Falastineya manzo'at al selah," Al Jazeera, (June 14, 2009), retrieved December 25, 2019, from http://bit.ly/2km3JrN. 